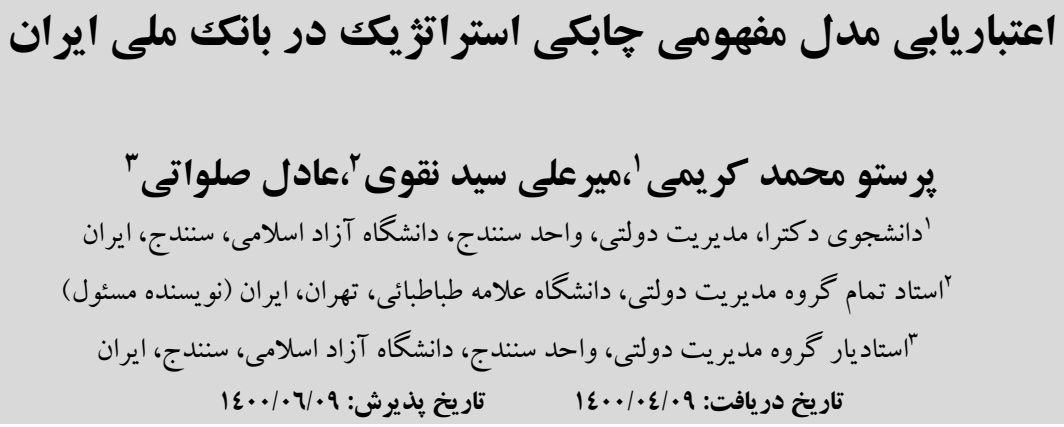

\title{
Evaluating A Conceptual Model Of Strategic Agility In Bank Melli Iran
}

\section{Parastou Mohamad Karimi ${ }^{1}$, Mir Ali Seyyed Naghavi ${ }^{2}$, Adel Salavati ${ }^{3}$}

${ }^{1}$ PHD student, Department of Public Administration, Sanandaj Branch, Islamic Azad University, Sanandaj, Iran

${ }^{2}$ Full professor, Department of Public Administration, Allameh Tabatabai University, Tehran, Iran,

(Corresponding Author)

${ }^{3}$ Assistant Professor, Department of Public Administration, Sanandaj Branch, Islamic Azad University, Sanandaj, Iran

Received: (30/06/2021) Accepted: (29/08/2021)

\section{شناسه يكتا:https://dorl.net/dor/}

\section{Abstract}

Given the importance of strategic agility in banks, the purpose of research is to evaluate the designed strategic agility model by the researcher in BankMelli. The model, which is the result of Meta-Synthesis and Delphi-method, consists of 4 main dimensions, 11 components and 34 indicators. The statistical population includes the official employees of Bank Melli with specialized jobs working in the offices units in Tehran (946 people). The sample size was determined based on Cochran's formula (275 people) and sampling was done randomly. The data collection method was the use of a researcher-made questionnaire based on the extracted model, which Its validity and reliability was confirmed using content validation and Cronbach's alpha. Testing the model in BankMelli, using statistical tests such as confirmatory factor analysis (second order) using Chi-square test and examining the fitness of RMSEA, P-value, $\chi^{2 / d f}$ indicators as well as T-test were performed and the model was evaluated.

\section{Keywords}

Strategic Agility Model, Vision Clarity, Responding, Strategic Sensitivity, Strategic

Collective

\section{جكيده} نظر به اهميت جابكى استراتزيك در بانكها، هدف يزّوهش، اعتباريابى مدل جابكى استراتزيك طراحىشده توسط محقق در بانك ملى ايران مىباشد. مدل مذكور كه حاصل اجراى يزوهش به -

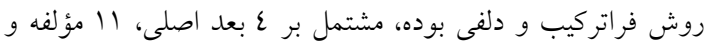

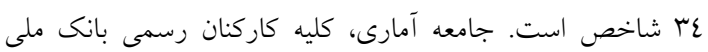
داراى مشاغل تخصصى شاغل در ادارات امور و واحدهاى ستادى تهران (927 نفر) بوده كه حجم نمونه بر اساس فرمول كوكران تعيين (rVO نفر) و نمونه كيرى به روش تصادفى انجام يذيرفت. روش كردآورى اطلاعات، استفاده از يرسشنامه محققساخته بر

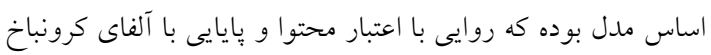
تائيد كرديد. آزمون مدل در محيط واقعى بانكى ملى، با كمى آزمونهاى آمار استنباطى از قبيل تحليل عاملى تأييدى مرتبه دوم با باديا

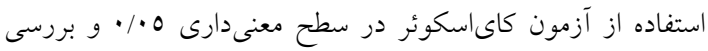
تناسب شاخصهاى RMSEA، (P-value، آزمون T، انجام و اعتبار مدل تأييد كرديد.

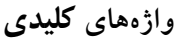

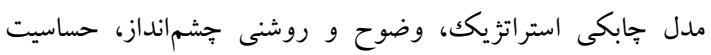

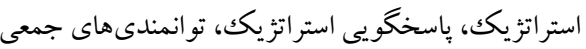


شرايط بيجيده و متغير، نارسايىها و ضعفهاى رويكرد سنتى مديريت استراتزيك در برخورد با حلقههاى گسسته موجود بين يك سازمان و محيطش آشكار شده (ديون يورت و همكاران،

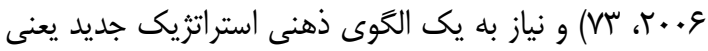
جابكى استراتزيك كه يكى از رويكردهاى جديد در مبحث

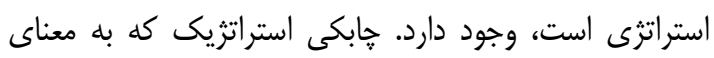
توانايى ياسخكَويى و واكنش سريع و موفقيتآميز نسبت به إنه

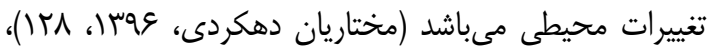
تقريباً تمامى شيوههاى قديمى انجام كار را كه مناسب شرايط

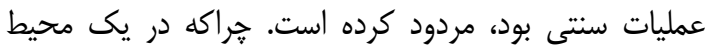

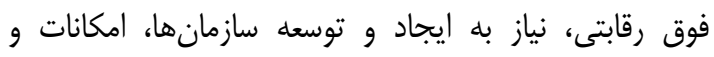
تجهيزاتى مىباشد كه بسيار منعطف بوده و حساسيت بالايى نيى نسبت به تغييرات داشته باشند (بائى و همكاران، هوسب، هأ). در واقع وضعيت بحرانى موجود، موجب اصلاحات عمدهاى در جشهانداز استراتزيك سازمانها، اولويتهاى كسبوكارى و وإن

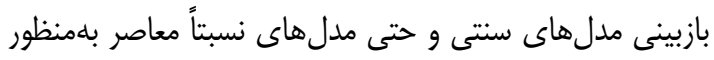
بهبود فعاليت رقابتى در اين كونه محيطها كَرديده است. لانگ

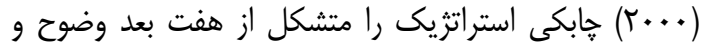
روشنى קشهانداز، دانش اربابرجوعها، فهميدن قابليتهاى بنيادين، انتخاب آماج و اهداف استراتزيك، مسئوليتيذيرى

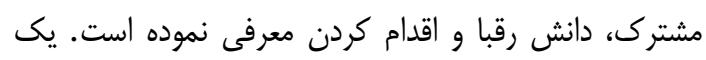
تعريف سلبعدى از خابكى استراتزيك توسط سامبامورتى و

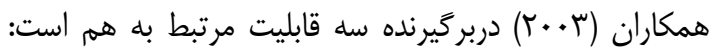
حابكى مشترى؛ هابكى عملياتى و هابكى شركا. اما رايجترين

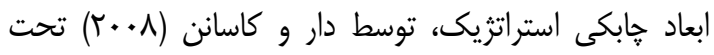

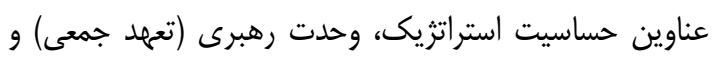
سياليت منابع معرفى شدند. در مطالعه ديخرى ماونگر (با. +r) ابعاد برجسته حساسيت استراتزيك، ياسخكويى استراتزيك و توانمندىهاى جمعى را براى هابكى استراتزيك مشخص

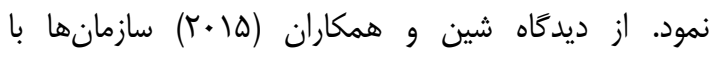
بهكاركيرى حابكى استراتزيك، مىتوانند نسبت به تغييرات سريع و غيرقابل بيشيبنى و فشارهاى محيطى باسخكًو بوده كه اين קاسخكويى عملياتى بهبوديافته، رضايت مشتريان و وائه عملكرد مالى را افزايش خواهد داد. از سوى ديخر بر اساس باس

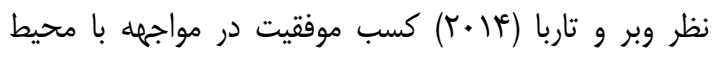
متغير امروزى مستلزم نوسازى مدلهاى فعلى كسبوكار مىباشد هراكه در بيشتر صنايع، قطعيتى در مورد مناسب بودن

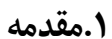

امروزه صنعت بانكدارى بلعنوان يك بازوى اقتصادى نقش ويزماى در رشد و شكوفايى اقتصاد كشورها ايفا مى كند. در ميان بانكهاى داخلى نقش بانك ملى ايران در توسعه و رونق اقتصادى كشور بر كسى يوشيده نيست؛ اما بديهى است كه همانند ساير سازمانها، محيط كسبوكار در حند دهل كذانشته براى بانكها از جمله بانك ملى نيز بلهور اساسى تغيير كرده

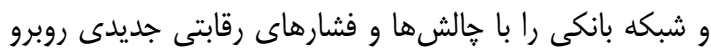
نموده است. در جنين شرايطى توانمندى بانكها براى تطبيق سريع و دقيق با شرايط در حال تغيير، يك عامل كليدى براى بقاى اثربخش و موفقيت در آينده است. هراكه در شرايط

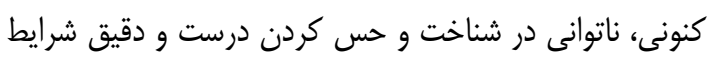
بيرونى و درونى بانك و در نتيجه عدم اتخاذ راهبردها و سياستهاى مناسب و سريع بلمنظور واكنش و ييش كنش در برابر اين شرايط، منجر به از دست دادن سهم بازار و كاهش بها

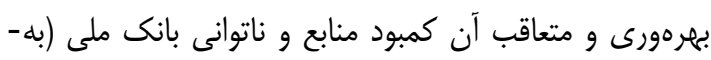

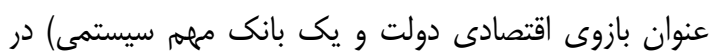
اعطاى تسهيلات و در نتيجه عدم موفقيت در روانسازى و بهبود خرخه اقتصاد كشور و همجنين ايفاى وظايف و مسئوليتهاى اجتماعى خود مى كردد كه تبعات آن علاوه بر بانكها مىتواند كل جامعه را نيز دركير نمايد. مى توان كفت بررسى عملكرد نظام بانكى كشور، بيانكر عدم موفقيت مناسب نظام مربوطه در تجهيز منابع و تخصيص بهينه و مطلوب آن بوده و همواره اين يرسش مطرح است كه جرا با وجود داشتن منابع مادى و انسانى، توانايى ارائه سيستمها و فرآيندها،

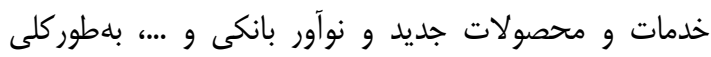
افزايش بهرهورى مناسبى در بانكى مشاهده نشده است. لذا اين موقعيت حياتى منجر به آن شده كه بسيارى از بانكها از جمله بانكى ملى در ديدكاههاى راهبردى خود تجديدنظر نموده

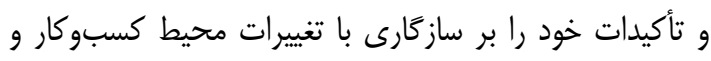
ياسخ بسيار سريع به نيازهاى مشتريان از طريق رويكردهاى جديد قرار دهند كه همان مصداق קابكى استراتزيكه است. קرا كه در جنين محيطى، رويكردها و راهحلهاى كذشتته،

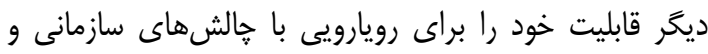
محيط بيرونى از دست دادهاند و لازم است با رويكردها و وائا ديدكاههاى جديدى جايكزين شوند (مختاريان دهكردى، عهسا، وץו). در حوزه استراتزيك نيز مىتوان كفت در اين 


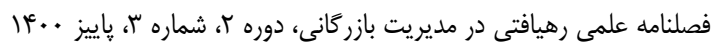

\section{r. جارجوب نظرى و يِيشينه يزوهش}

ץ-1 - קابكى استراتزيك

קگَونكى دستيابى به קابكى استراتزيك از آغاز مديريت

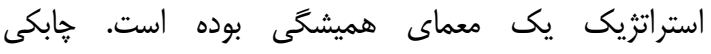

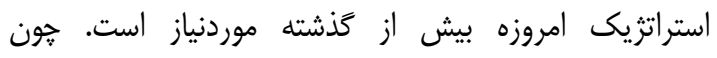
شركتها بيشتر و بيشتر در معرض تغييرات سريع و يبيجيدهاند و واكنش به اين تغييرات مستلزم جابكى استراتزيك است (دار،

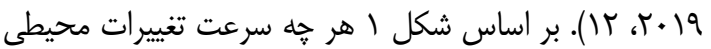

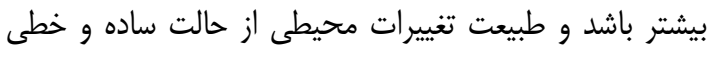
به طرف بيجِيده و سيستماتيك ميل كند، نياز به رويكرد جابكى استراتزيك بيشتر خواهد شد.

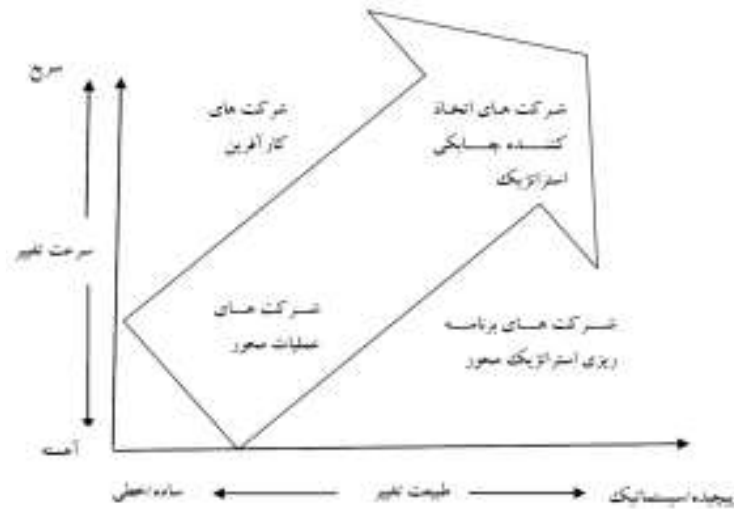

شكل (ـ شدت نياز به קֶابكى استراتزيك بر اساس

شرايط محيط(منبع: داز و كاسانن، •وسا، استراتزى سريع)

קابكى استراتزيك تحت عناوين مختلف بيان شده است. از اواخر دهه •9 بحث هابكى استراتزيك به معناى توانيى اصلاح، نوسازى و بازآفرينى سازمان، مدلهاى كسبوكار و إنائ راهبردهايش منطبق بر تغييرات محيطى ارائه شد. اين مسئله از طريق ييشينى مستمر و انطباق با روندها و نيازهاى مشتريان، بدون رها كردن جشمانداز سازمان امكانيذير است (روث، 9991،بr). روث (1999) קابكى استراتزيك را بهعنوان توانايى توليد محصولات درست در زمان درست، در مكان درست و با قيمت درست بكار برد. هر جند روث (1998) عبارت خابكى استراتزيك را بكار برد ولى مفهوم آن بسيار نزديك به مفهوم جابكى توليد بود (شين و همكاران، ها •r، هم1). اما در دنياى آكادميك، קابكى استراتزيك به مفهوم

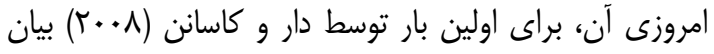

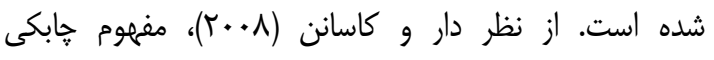

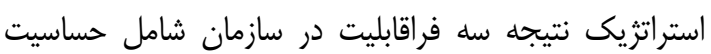

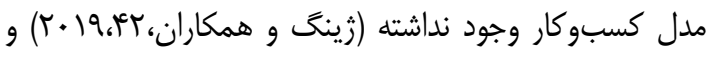
شركتها بايد قادر باشند از طريق مدلهاى كسبوكار جديدتر و روشهاى بايدارترى به رقابت ببردازند (وبر و تاربا، عاء +r،

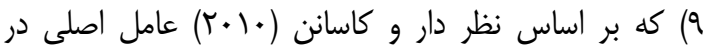
توانايى تغيير و تجديد مدلهاى كسبوكار، همان קابكى استراتزيك مىباشد. مطالعات انجام شده در زمينه קابكى

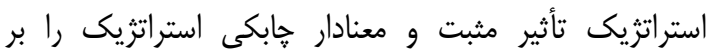
شاخصهاى حوزه رقابت مشتمل بر قابليتهاى رقابتى (اوجها

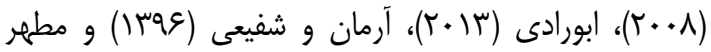

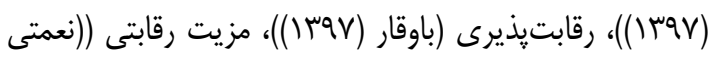

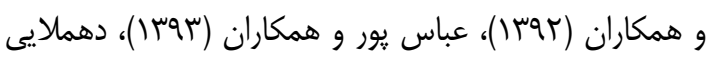

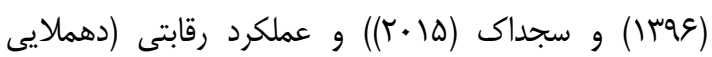
(وجسا)) نشان مىدهند. لذا استنباط مىشود بانك با اتخاذ رويكرد קابكى استراتزيك مىتواند در عرصه رقابت موفق

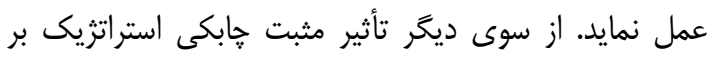

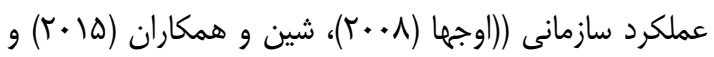

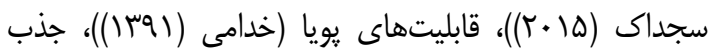
مشترى (شين و همكاران (ها •r))، نوآورى استراتزيك (آرمان

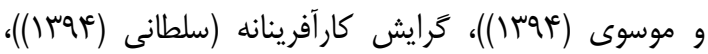
مقولههايى همجون توانمندى فنى، يادگيرى سازمانى و

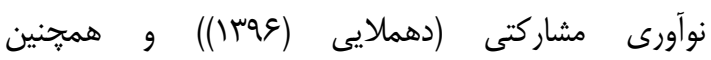
انعطافيذيرى، كيفيت خدمات، اطمينان از ارائه خدمات، نوآورى و رهبرى هزينه (مطهر (Vوسו)) در مطالعات مختلف به اثبات رسيده است. در حوزه بانكى نيز تأثير مثبت و معنادار קابكى استراتزيك بر عملكرد بانكها (اوفوكبى و آكانبى ناتيى

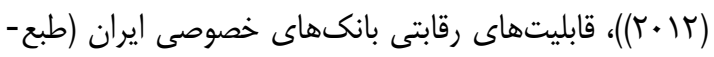

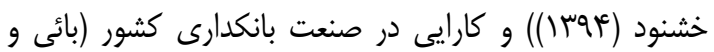
همكاران (هوس()) نشان داده شده كه همكى بر الهميت و الهائ نقش استقرار حابكى استراتزيك در دستيابى به موفقيت توسط

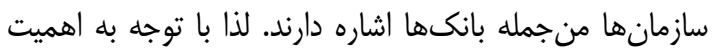

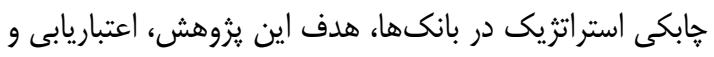
آزمون مدل طراحىشده توسط محقق در زمينه קابكى استراتزيى (يس از طى مراحل فراتركيب و دلفى)، بلمنظور

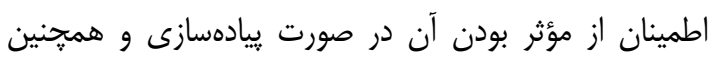

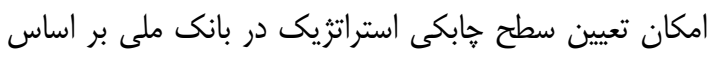

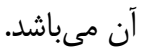


استراتزيك در مورد نوسازى سازمان و نوآورى در مقابله با

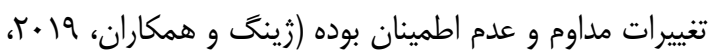
ه و و به عبارتى ديخر "تصميمَيرى بلموقع براى اجراى استراتزىهاى تجارى در ييش كنش يا در واكنش به روندهاى

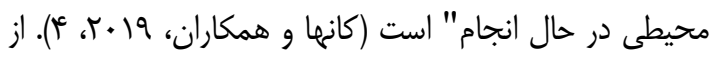

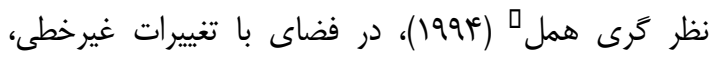

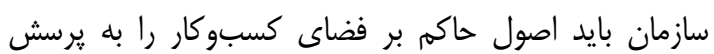
كيرد و بهبود و نوآورى بايد بلطور همزمان صورت كيرد تان قبل از بروز بحران، سازمان ها خود را با آن هماهنح كنند. اين

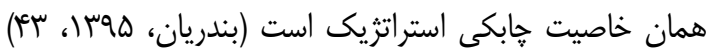

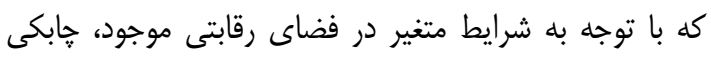
استراتزيك امرى ضرورى و مهم براى آنها جلوه مى كند. r-r جدول ا مطالعات صورت كرفتنه در خصوص شناسايى ابعاد جابكى استراتزيك را نشان مىدهد.

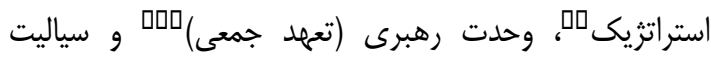

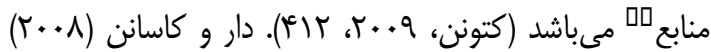
קابكى استراتزيك را "توانايى تنظيم و انطباق مداوم جهت گيرى استراتزيك در كسبوكار اصلى، بهعنوان تابعى از بلنديروازىهاى استراتزيك و رويدادهاى در حال تغيير و ايجاد

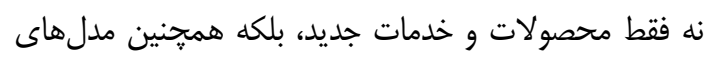
كسبوكار جديد و شيوههاى نوآور بلمنظور ايجاد ارزش براى شركت"معرفى كردهاند. همجنين جابكى استراتزيك توانايى سازمان در كشف فرصتهاى جديد مزيت رقابتى و استفاده از دانش، دارايىها و روابط بهمنظور تصاحب اين فرصتهاست

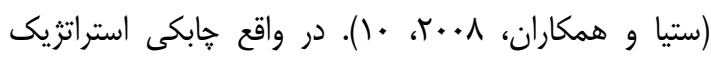
بهنوان توانايى تشخيص و بهرهبردارى سريع از فرصتها، مديريت تغيير و اجتناب از تضاد، مىتواند سازمان را در مواجها

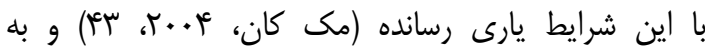

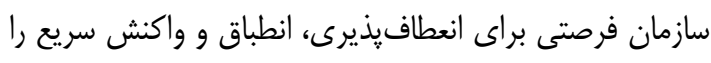

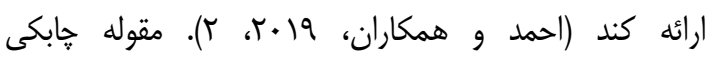

جدول ا. ابعاد خابكى استراتزيك در مطالعات مختلف

\begin{tabular}{|c|c|}
\hline \multicolumn{2}{|c|}{ ابعاد استفاده شده براى جابكى استر اتزيك } \\
\hline \multicolumn{2}{|c|}{ 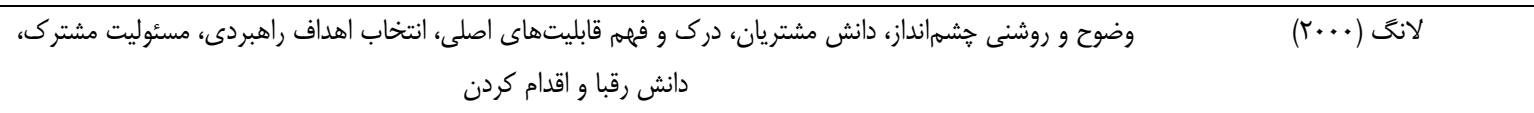 } \\
\hline \multicolumn{2}{|c|}{ خابكى مشترى، خابكى عملياتى و خابكى شركا } \\
\hline \multicolumn{2}{|c|}{ جشم|نداز واضح، انتخاب اهداف راهبردى، شناسايى توانمندى هاى كليدى، تسهيم مسئوليت و بهرببردارى } \\
\hline \multicolumn{2}{|c|}{ 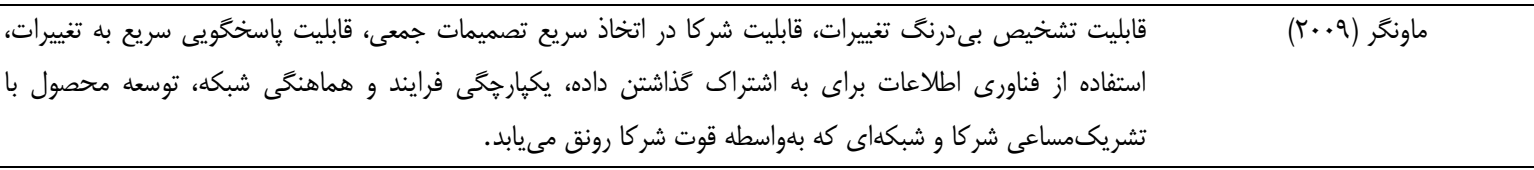 } \\
\hline ك، ياسخگويى استراتزيك و توانمندىهاى جمعى & 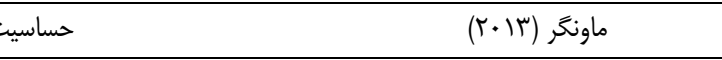 \\
\hline إحدت رهبرى، روان بودن منابع و كشش سازمانى & 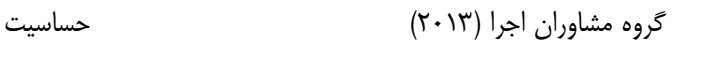 \\
\hline 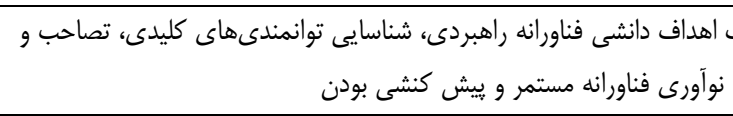 & حساسيت راهبردى، خشمانداز روش \\
\hline 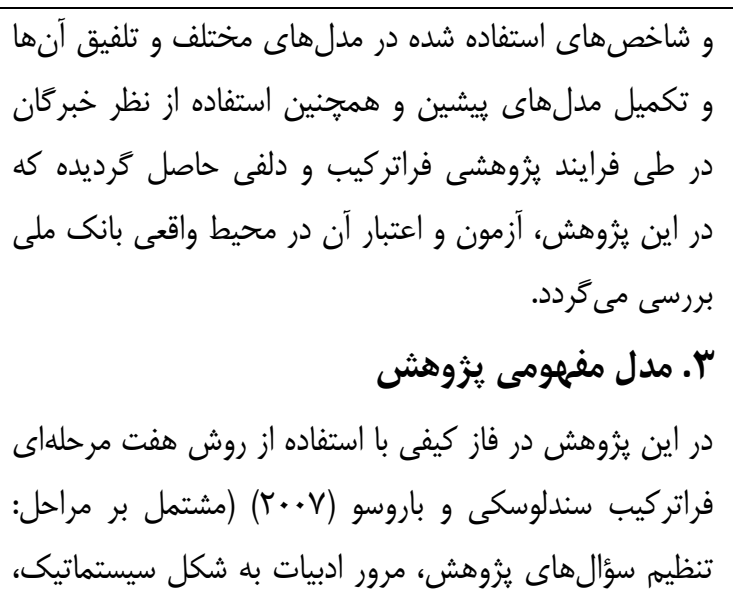 & 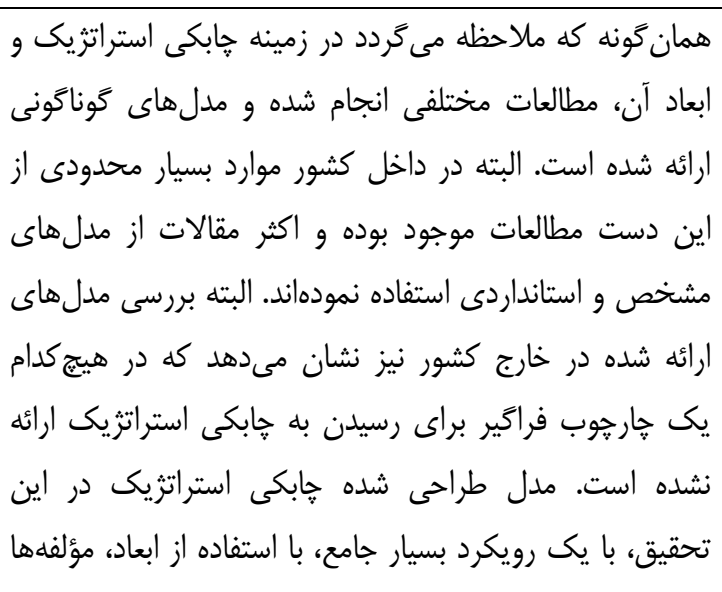 \\
\hline
\end{tabular}




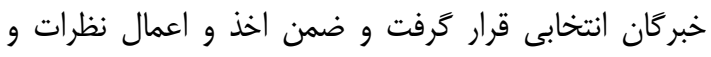
ييشنهادات تكميلى مبنى بر تغيير، حذف و يا افزودن موارد

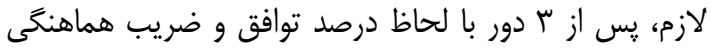

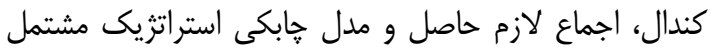

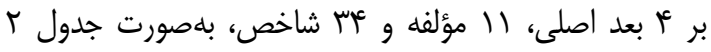

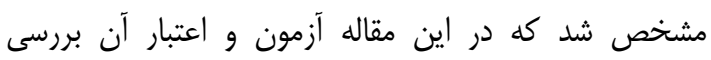

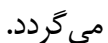

جستجو و انتخاب متون مناسب، استخراج اطلاعات متون، تجزيهوتحليل و تركيب يافتهاى كيفى، كنترل كيفيت

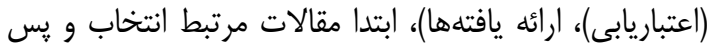

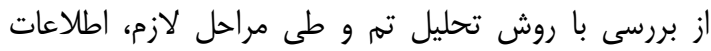
مرتبط استخراج و كدهاى مفهومى اوليه، شاخصها (كدهاى

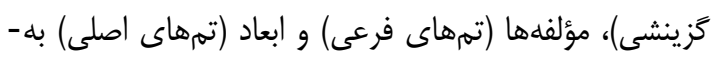

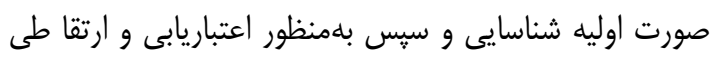
يك فرآيند يزوهشى با تكنيك دلفى در معرض سنجش ينّافي

جدول ז. ابعاد، مؤلفهها و شاخصهاى سازه هابكى استراتزيك (منبع: يافتههاى يزوهشخًر)

\begin{tabular}{|c|c|c|}
\hline شاخصها (كدهاى كَزينشى) & مؤلفهها (تمهاى فرعى) & ابعاد (تمهاى اصلى) \\
\hline مشاركت در تعيين جشم|نداز & \multirow{2}{*}{ 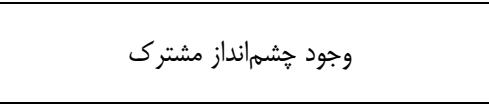 } & \multirow{6}{*}{ 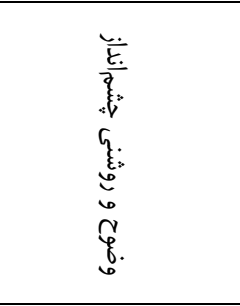 } \\
\hline اطمينان از درى و يذيرش جشمانداز & & \\
\hline مشاركت در تعيين بيانيه مأموريت & \multirow{2}{*}{ وجود مأموريت سازمانى شفاف } & \\
\hline اطمينان از درك و يذيرش بيانيه مأموريت & & \\
\hline مشاركت در تعيين كزارههاى ارزش & \multirow{2}{*}{ ايجاد منطق يكيار خه ارزشى در راستاى خشم|نداز } & \\
\hline اطمينان از درك و يذيرش كزارههاى ارزش & & \\
\hline (بناسايى الخَو (بلندمدت) & \multirow{2}{*}{ ي ي بيشينى استراتزيك } & \multirow{8}{*}{ 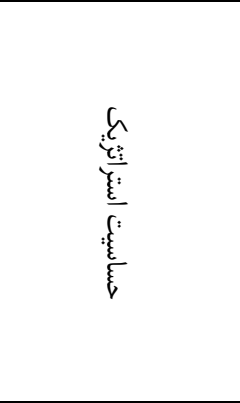 } \\
\hline شناسايى تغييرات مسير (كوتاممدت) & & \\
\hline حس كردن بيرونى خابك & \multirow{3}{*}{ بينش استراتزيك } & \\
\hline آكاهى درونى خابك & & \\
\hline درى و فهمم قابليتهاى اصلى & & \\
\hline ارتباط مؤثر بين كاركنان & \multirow{3}{*}{ 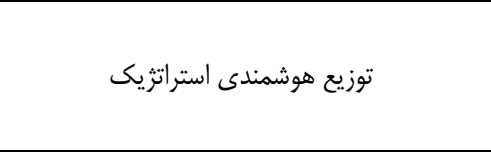 } & \\
\hline ارتباط مؤثر بين مديران و كاركنان & & \\
\hline ارتباط مؤثر بين مديران بخشهاى مختلف & & \\
\hline سياليت منابع & \multirow{3}{*}{ ياسخحَويى درونى } & \multirow{5}{*}{ 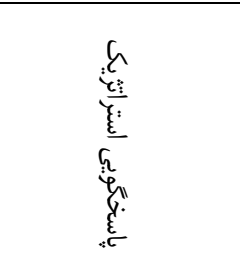 } \\
\hline جابكى عملياتى (بلوغ فر آيندهاى كسبوكار) & & \\
\hline انتخاب مداوم اهداف استراتزيك & & \\
\hline ياسخخويى واكنشى (منفعل) حابك & \multirow[b]{2}{*}{ 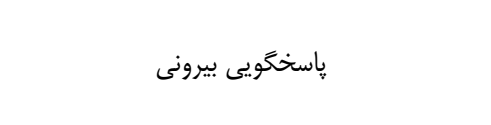 } & \\
\hline ياسخكَويى ييش كنشى (فعال) جابى & & \\
\hline وحدت رهبرى (تعهد جمعى) & \multirow{10}{*}{ توانمندىهاى منابع اطلاعاتى و فناورى اطلاعات } & \multirow{15}{*}{ 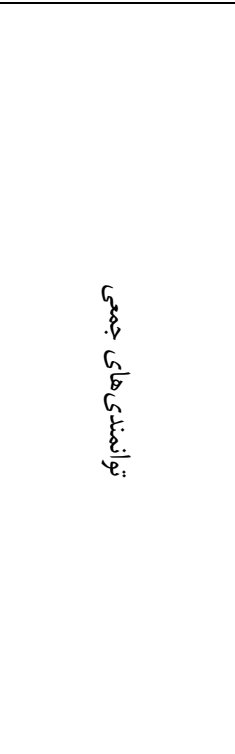 } \\
\hline جهت كيرى جمعى & & \\
\hline مديريت و رهبرى مؤثر & & \\
\hline مديريت دانش و يادكيرى سازمانى & & \\
\hline 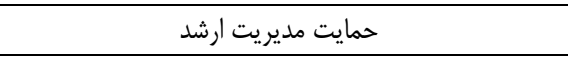 & & \\
\hline همكارى و شايستخى كاركنان & & \\
\hline ساختار شبكه اطلاعاتى و ارتباطاتى مناسب & & \\
\hline 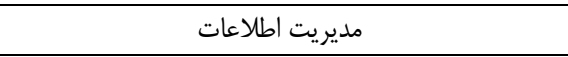 & & \\
\hline قابليتهاى فناورى اطالاعات (سختافزارى و نرمافزارى) & & \\
\hline يكيارجخى زيرساختهاى سيستمهاى اطلاعاتى و ارتباطى & & \\
\hline \multicolumn{2}{|l|}{ فرهنى سازمانى مناسب } & \\
\hline \multicolumn{2}{|l|}{ ساختار دووجهى (باثبات و منعطف) } & \\
\hline كشش سازمانى & \multirow[t]{3}{*}{ توانمندى هاى زيرساختارى } & \\
\hline جو سازمانى مثبت & & \\
\hline يكيارجگى و هماهنگى & & \\
\hline
\end{tabular}



نمودار (. مدل مفهومى يزوهش (منبع: يافتههاى يزوهشكر)

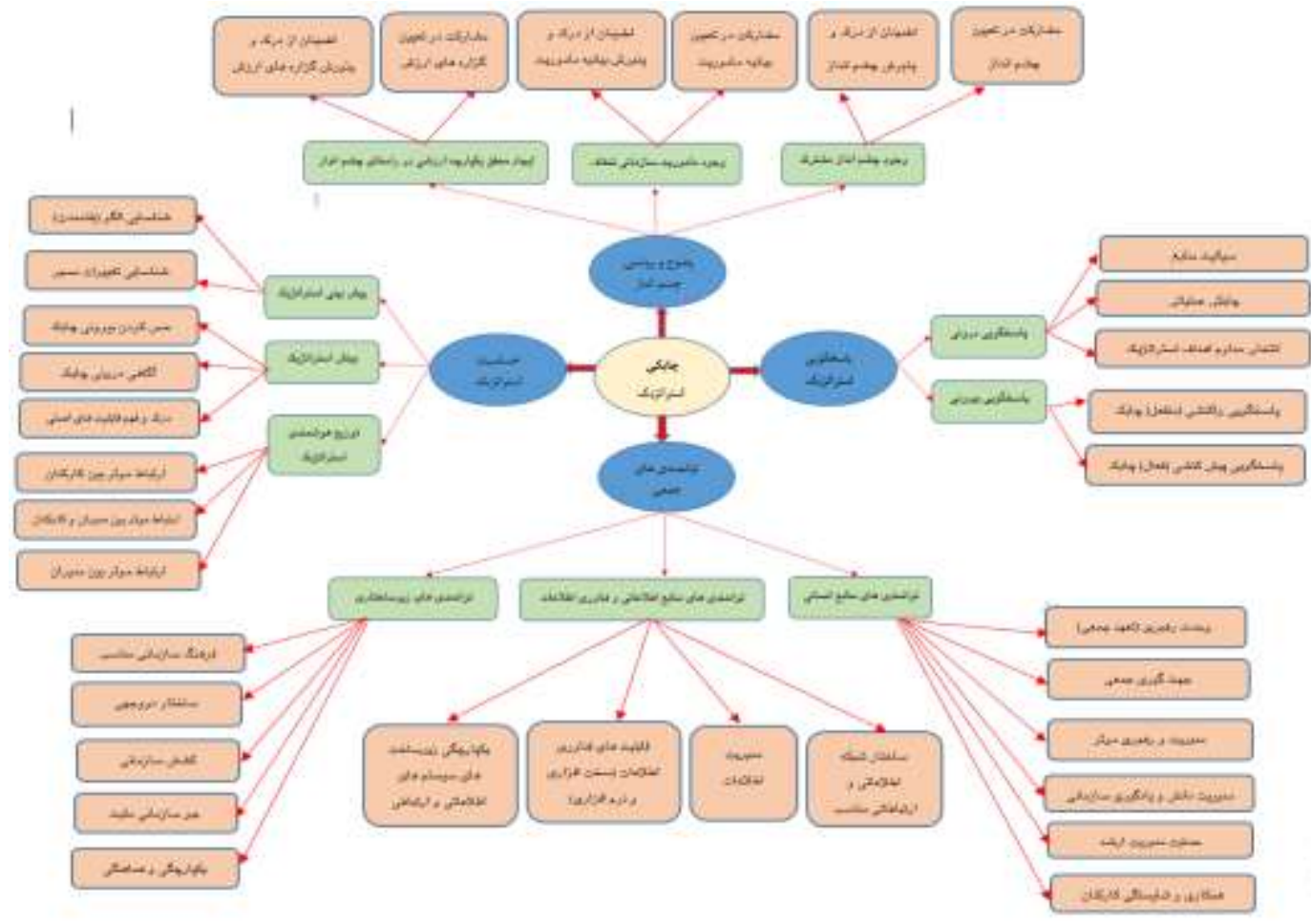

نمونه انتخاب كَرديدند.

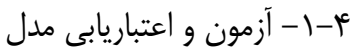

ع.روش يزوهش، تحليل داده ها و يافتههاى

در اين مرحله آزمون مدل بهمنظور اطمينان از مناسب بودن

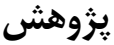

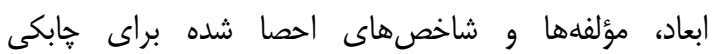
استراتزيك، در مطالعهاى ميدانى و با استفاده از اطلاعات يرسشنامه صورت كرفت. در اين يزوهش تعداد .بr فقره

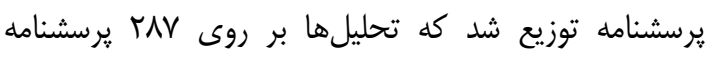
برَّتى و قابل قبول انجام و نتايج ارائه كَرديد. تجزيهوتحليل دادهها با استفاده از تكنيك تحليل عاملى تأييدى مرتبه دوم با

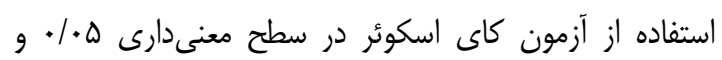

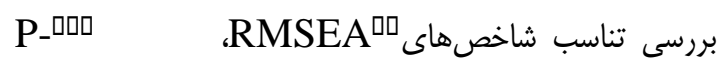

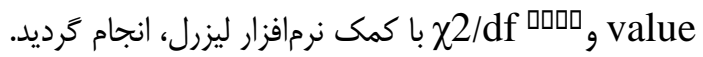
ץ-1-1-1- تحليل عاملى تأييدى مرتبه دوم

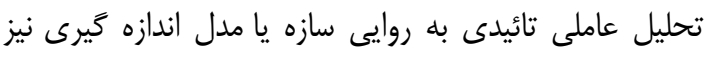

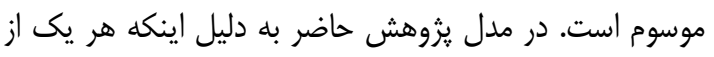

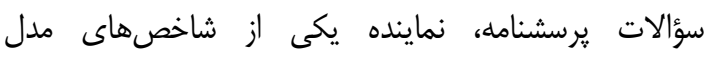

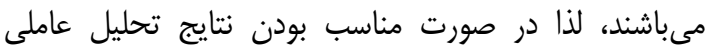

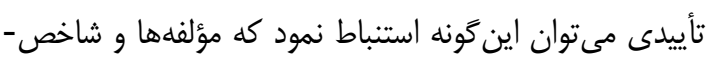
تحقيق حاضر از لحاظ هدف كاربردى و از نظر ماهيت و روش

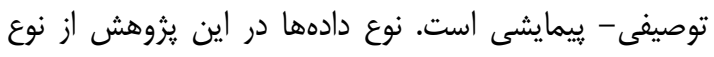

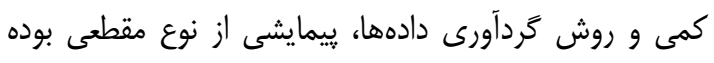

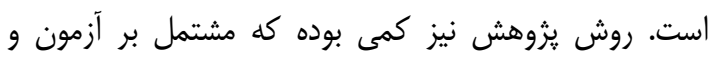

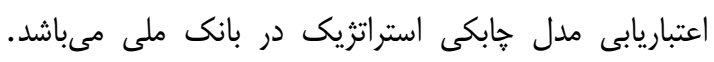
جمع آورى دادههاى لازم، با استفاده از يرسشنامه محقق ساخت داخته

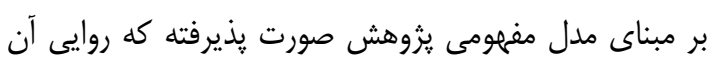

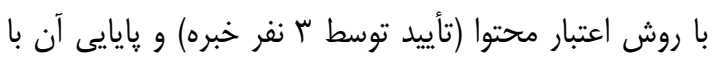

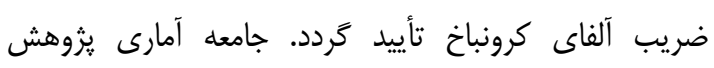
كاركنان داراى مشاغل تخصصى (كارشناسان و بازرسين) رسمى شاغل در ادارات امور و واحدهاى ستادى بانكى ملى داري

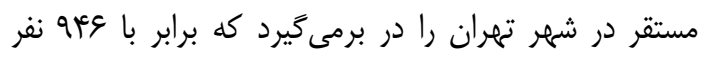

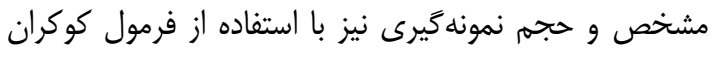

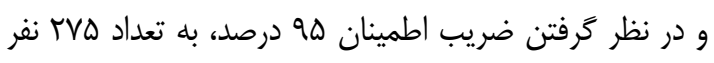
مشخص كرديد كه بر اساس روش نمونهكيرى تصادفى افراد 
محمد كريمى،سيدنقوى،عادل صلو اتى:اعتباريابى مدل مفهومى جابكى استراتزيك در بانكك ملى ايران

مناسب بودن شاخصهاى مذكور، در ادامه به بررسى معنادار

هاى انتخابشده بdخوبى انتخاب و تعيين كَرديدهاند. بهنظور

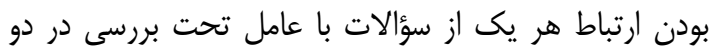

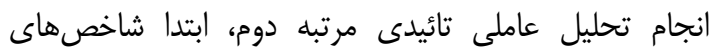
حالت استاندارد بودن و معنادارى مىيردازيه.

برازش كلى مدل تحليل عاملى تأييدى مرتبه دوم را مطابق

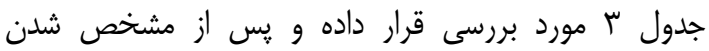

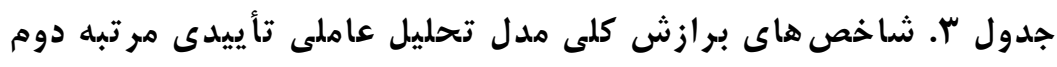

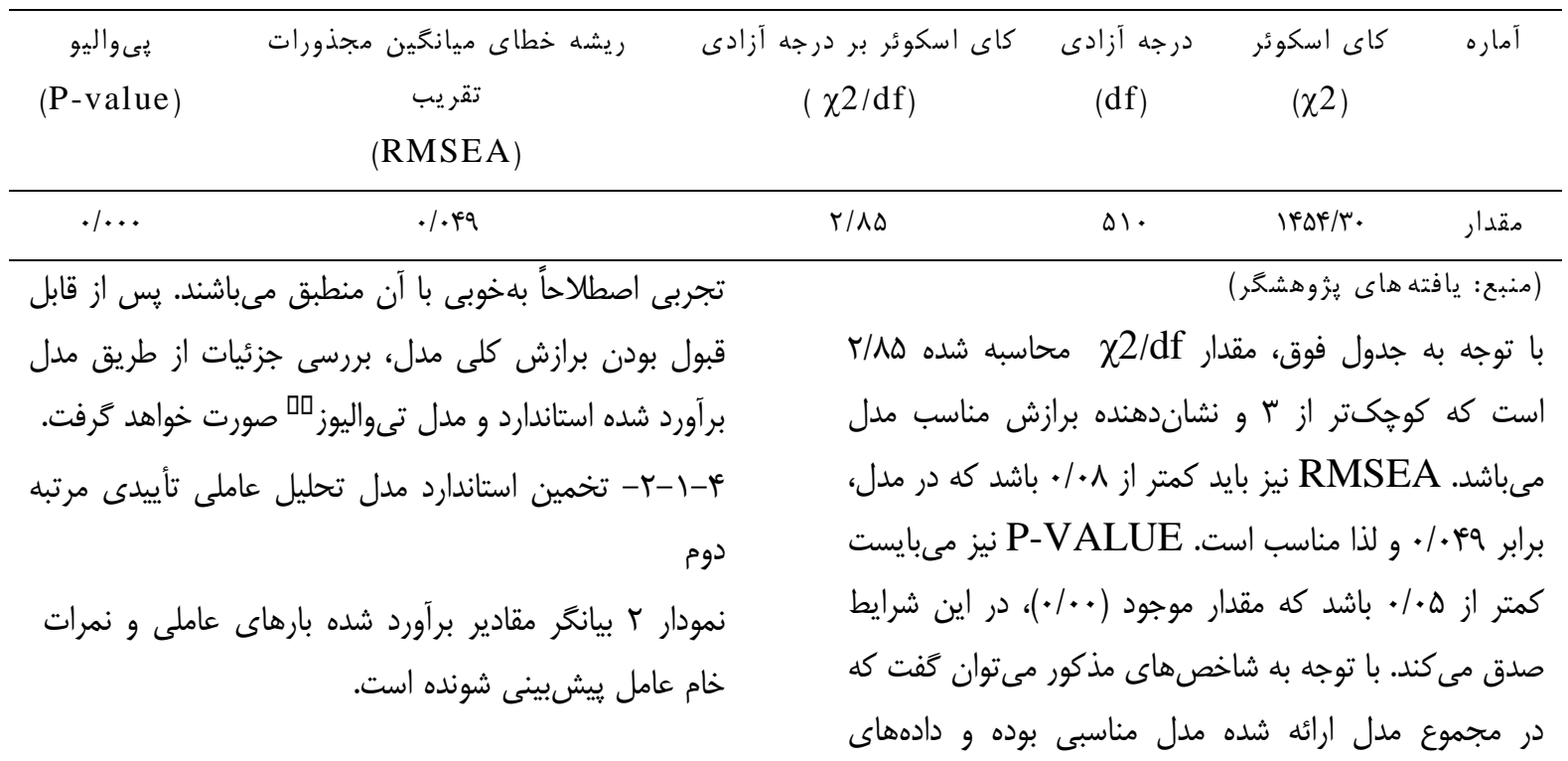

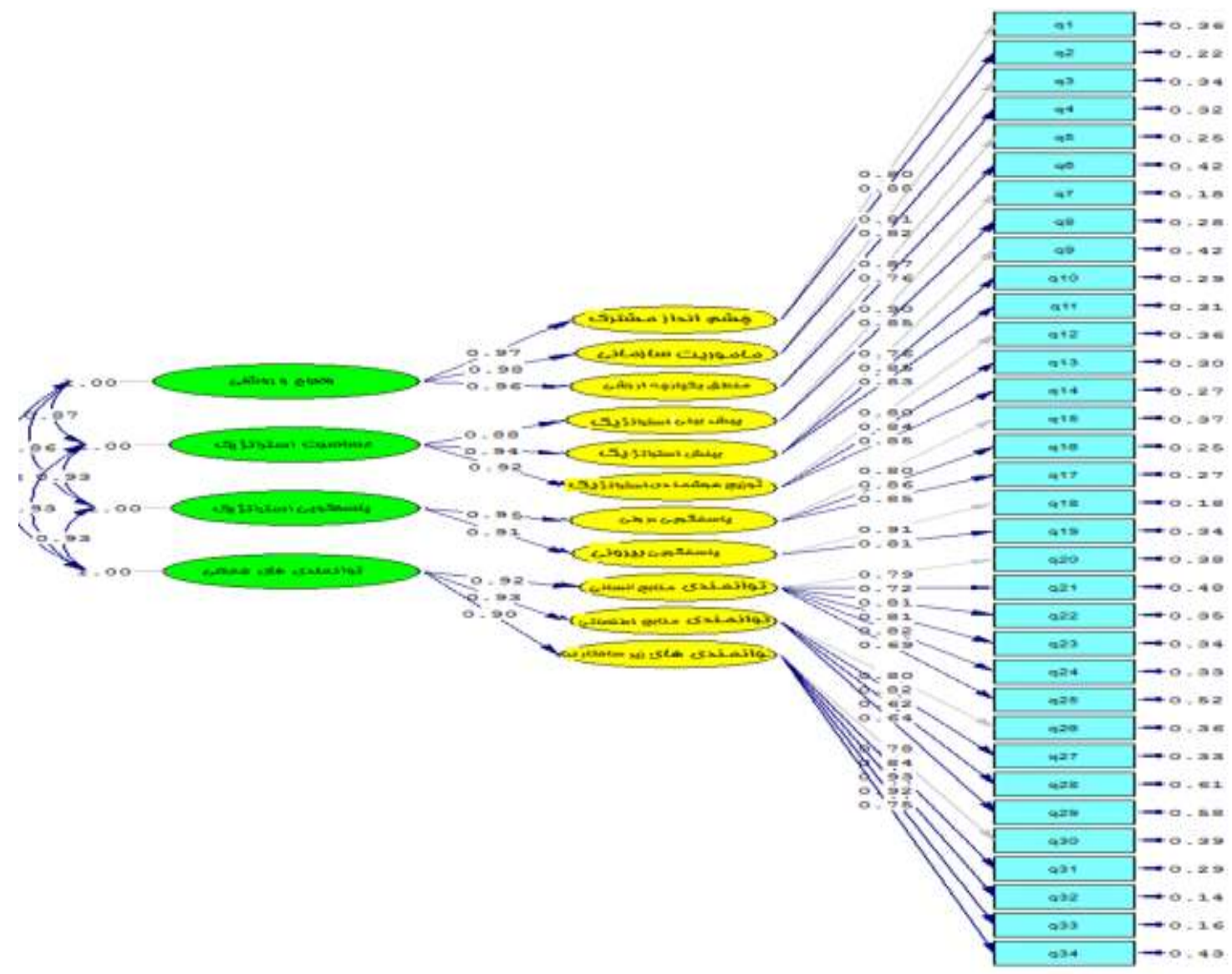

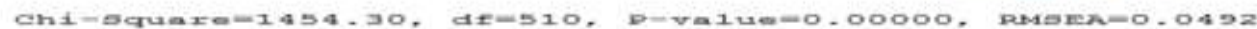


نمودار r. تخمين استاندارد مدل تحليل عاملى تأييدى مرتبه دوم (منبع: يافتههاى يزوهشكًر)

حال به بررسى معنادارى مدل استاندارد با تشكيل مدل تيواليوز مطابق نمودار س مىيردازيم.

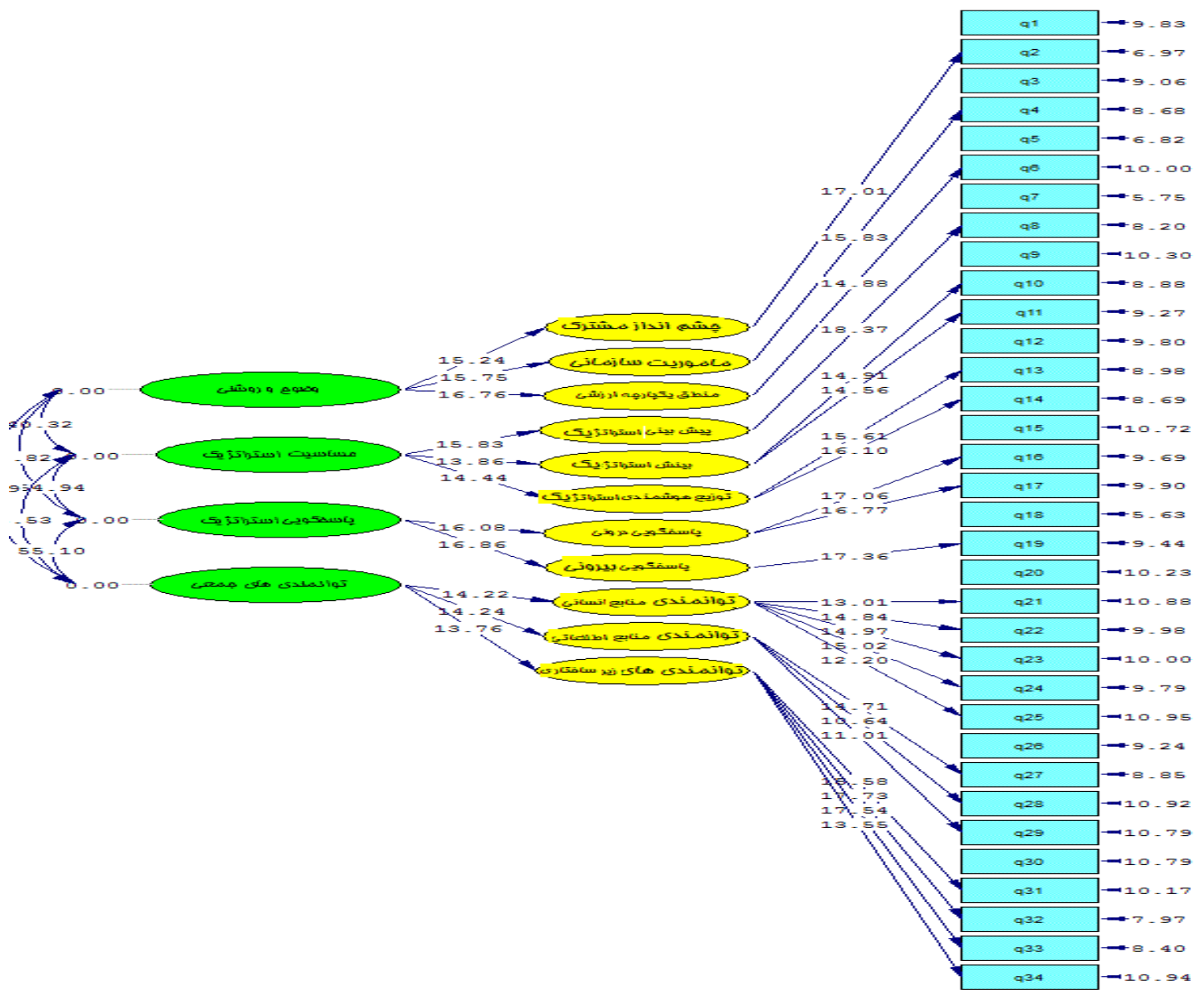

Chi-square=1454-30, df=510, P-value=0.00000, RMSEA=0.0492

نمودار سّ. مدل تىواليوز تحليل عاملى تأييدى مرتبه دوم (منبع: يافتههاى يزوهشكَر)

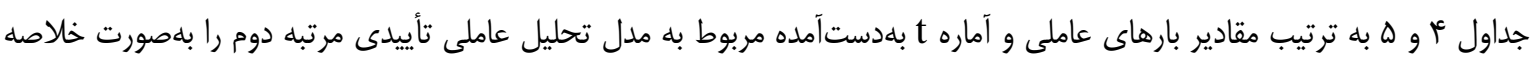
نشان مىدهند.

جدول ع. بارهاى عاملى و آماره t در تحليل عاملى تأييدى (بخش اول نمودار)

\begin{tabular}{|c|c|c|c|c|c|c|c|}
\hline آماره t & بار عاملى & كويه & مؤلفه & آماره t & بار عاملى & كويه & مؤلفه \\
\hline $19 / 1 r$ &.$/ 94$ & 11 & \multirow[t]{2}{*}{ ياسخكَويى بيرونى } & $19 / 1 f$ & $\cdot|\wedge|$ & 1 & \multirow[t]{2}{*}{ وجود جشم|نداز مشتر ك } \\
\hline $1 Q / V \wedge$ &.$/ 1$ & 19 & & $\mathrm{IV} / \mathrm{Vq}$ & ./AV & $r$ & \\
\hline ID/Tr & $\cdot / \mathrm{V} \Lambda$ & $r$. & \multirow[t]{4}{*}{ توانمندى هاى منابع انسانى } & $\mid \varepsilon / \mu_{0}$ & . /At & r & \multirow[t]{2}{*}{ وجود مأموريت سازمانى } \\
\hline $1 \pi / 4$ & $\cdot / \mathrm{VI}$ & r) & & $10 / 91$ & $\cdot|\wedge|$ & r & \\
\hline $18 / 4 T$ & $\cdot|\mathrm{A}|$ & tr & & $\mathrm{IV} / \cdot \mathrm{V}$ &.$/ N E$ & $\Delta$ & \multirow[t]{2}{*}{ ايجاد منطق يكيارجه ارزشى } \\
\hline $18 / T V$ & $\cdot|\wedge|$ & r & & $\mid F / \Delta T$ & $\cdot / V G$ & 8 & \\
\hline
\end{tabular}


محمد كريمى،سيدنقوى،عادل صلو اتى:اعتباريابى مدل مفهومى جابكى استراتزيك در بانكك ملى ايران

\begin{tabular}{|c|c|c|c|c|c|c|c|}
\hline $1 \varepsilon / v \wedge$ & $\cdot / \Lambda \mu$ & re & & $\mid N / \uparrow \Lambda$ & .119 & $\checkmark$ & يِيشينى استراتزيك \\
\hline I & $\cdot / \mathrm{NI}$ & to & & IV/gY & $\cdot / \Lambda \varepsilon$ & $\wedge$ & \\
\hline $10 / 9$. & $\cdot / \Lambda$ & te & توانمندى هاى منابع اطلاعاتى & $10 / \% q$ &.$/ \mathrm{Vq}$ & 9 & بينش استراتزيك \\
\hline ( & ./AT & tr & & $I V / \Delta \Lambda$ & $\cdot / \Lambda 9$ & 1. & \\
\hline $11 / r$ & $.8 T$ & ru & & $\mid Q / M$ & $\cdot / \Lambda$ & 11 & \\
\hline $11 / 4 \Delta$ &.$/ 94$ & rq & & $I F / M$ & $\cdot / \mathrm{VV}$ & it & توزيع هوشمندى استراتثيى \\
\hline $10 / \% q$ &.$/ \mathrm{VV}$ & r. & توانمندىهاى زيرساختارى & $I V / \Delta \Lambda$ & $\cdot / \wedge \varepsilon$ & سו & \\
\hline $\mathrm{IV} / \mathrm{T}$. & ./Ar & r & & $\mathrm{V} / \cdot 9$ & $\cdot / \Lambda \Delta$ & 14 & \\
\hline$r \cdot \mid q r$ &.$/ 9 \mu$ & r & & $10 / v 9$ & $\cdot / \Lambda$ & 10 & ياسخگَّيى درونى \\
\hline$r \cdot / \mu$ &.$/ 95$ & 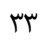 & & IN/ET & $\cdot / \mathrm{M}$ & 19 & \\
\hline $\mid \pi / 94$ &.$/ V \Delta$ & me & & $\mathrm{IV} / \cdot$. &.$/ A F$ & IV & \\
\hline
\end{tabular}

جدول ه. بارهاى عاملى و آماره t در تحليل عاملى تأييدى (قسمت دوم نمودار)

\begin{tabular}{|c|c|c|c|}
\hline 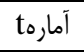 & بار عاملى & مؤلفه & بعد \\
\hline $1 \Delta / T^{F}$ &.$/ 9 V$ & وجود جشم|نداز مشترى & وضوح و روشنى جشمانداز \\
\hline $1 \Delta / V \Delta$ &.$/ 91$ & وجود مأموريت سازمانى & \\
\hline IS/VE & .199 & ايجاد منطق يكهارجه ارزشى & \\
\hline $10 / \wedge \mu$ & $\cdot / M$ & ييشينى استراتزيك & حساسيت استراتزيك \\
\hline Ir/N &.$/ 94$ & بينش استراتزيك & \\
\hline $\mid f / 4 x$ &.$/ 94$ & توزيع هوشمندى استراتزيى & \\
\hline $191 \cdot 1$ & .190 & ياسخخَويى درونى & ياسخحكويى استراتزيك \\
\hline IS/NE &.$/ 91$ & ياسخگويى بيرونى & \\
\hline $1 F / \pi$ &.$/ 94$ & توانمندى هاى منابع انسانى & توانمندى هاى جمعى \\
\hline $1 F / \pi F^{2}$ & . & توانمندى هاى منابع اطلاعاتى & \\
\hline $1 \% / v g$ &.$/ 9$ & توانمندىهاى زيرساختارى & \\
\hline
\end{tabular}

حابكى استراتزيك بر ساير حوزهها مىباشند. بلهوركلى، در

ادبيات خابكى استراتزيك اغلب بر تعداد اندكى از استراتزىها و ابزارها كه رسيدن به جابكى استراتزيك را تسهيل مى كنند، تمركز شده است و يك حار خوب جامع و فراكير براى رسيدن به جابكى استراتزيك على الخصوص در بانكها ارائه نشده است. در اين يزوهش پِ از انجام فاز كيفى تحقيق مدل مفهومى در خصوص اجزاء خابكى استراتزيك با استفاده از روش فراتركيب و دلفى استخراج كرديد. در فاز كمى تحقيق، اعتبار الكوى نهايى هابكى استراتزيك در محيط واقعى بانكى ملى، با روش تحليل عاملى تأيبدى مرتبه دوم، آزمون و تأييد كرديده و از مناسب بودن اجزاء استخراج شده براى سازه جابكى استراتزيك اطمينان حاصل شد. با توجه به اينكه بر اساس نتايج يزوهش، ارتباط بين اجزاى مدل در سطح بالايى بوده و روابط از استحكام بالايى برخوردار هستند، لذا مىتوان

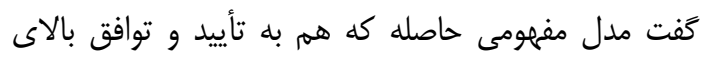
خبركان رسيده است و هم در محيط واقعى آزمون شده و اعتبار آن مورد تأييد قرار كَفته است، مىتواند بلهمنظور
(منبع: يافتههاى يثوهشكر) همان كَونه كه در جداول فوق ملاحظه مى كَرد، براى هر ير يارامتر در مدل يك مقدار t مشاهده شده به دست مى آيد كه تحليل آن بدينصورت مىباشد، زمانى كه تعداد نمونه بيشتر

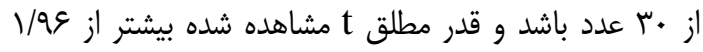
باشد با بيش از هو٪ اطمينان رابطه بهدستآمده معنى أرار

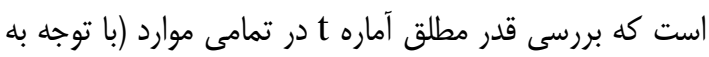
جداول فوق) با اطمينان هو٪ عدد بيشتر از عه/ را نشان داده و لذا كليه بارهاى عاملى معنادار بوده و دادههاى تجربى بهخوبى با مدل منطبق مىباشند، لذا اعتبار مدل تأييد مى مردد.

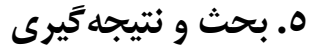

مطالعات و بررسىهاى انجام شده نشان مىدهد كه تحقيقات

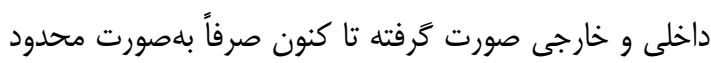
و ناقص، به بررسى ابعاد و شاخصهاى هابكى استراتزيك يرداخته و اكثر مطالعات انجام شده نيز در زمينه بررسى تأثير 
سازمانها مورد بهرهبردارى قرار كرفته و همجنين بلعنوان مبنايى براى سنجش سازه مذكور و نيز بهعنوان ابزارى براى تعيين سطح קابكى استراتزيك در سازمانهاى مختلف مورد

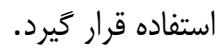

ييشنهاد مى شود در يزوهشهاى آتى قلمرو مكانى يروهش توسعه يابد و نتايج در بخشهاى ديخر بلهمنظور انتشار

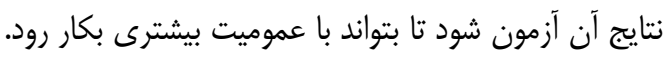

\section{فهرست منابع}

آرمان، مانى و موسوى (4وجا() بررسى تأثير حابكى استراتزيك

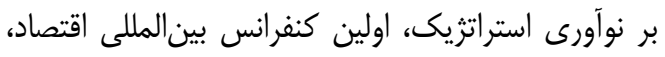

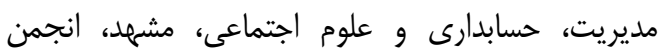
مديريت ايران.

آرمان، مانى و شفيعى (عوسا) قابليتهاى رقابتى در شركتهاى دانشبنيان مدلى براى تبيين نقش קابكى استراتزيك و

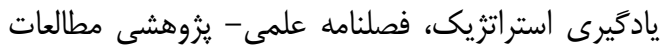

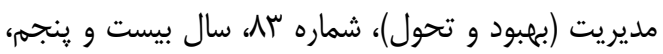

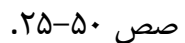

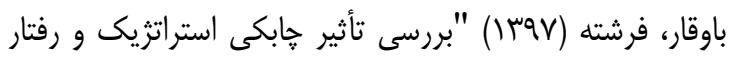

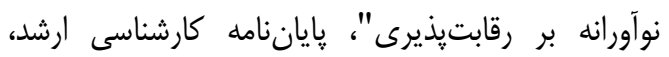

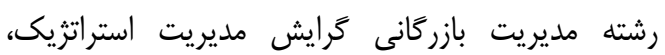

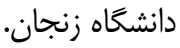
بائى، ساناز. كردنائيج و دلخواه (هوجا) קابكى استراتزيك در صنعت بانكدارى ايران و تأثير آن بر كارايى، دو فصلنامه

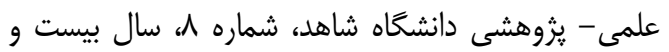

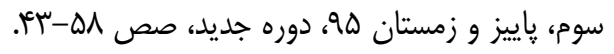
بندريان، رضا (هوسج) ارائه مدل مفهومى خابكى استراتزيك در

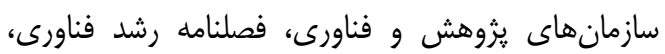
شماره ؤأ، بهار، سال دوازدهم. خدامى، سهيلا (اqسו) "طراحى مدل فعاليت رقابتى با رويكرد جابكى استراتزيك، بررسى نقش شايستخى IT هوشيارى كارآفرينانه و زيركى بازار"، رساله دوره دكترا، رشته مديريت كرايش بازاريابى بينالملل، دانشخاه تربيت مدرس

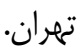

عملياتى سازى و استقرار קابكى استراتزيك در بانك ملى

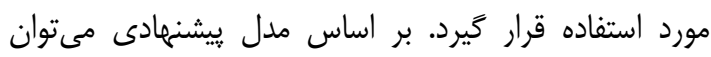
اينطور استباط نمود كه نقطه شروع و كام اول در استقرار جابكى استراترزيك در بانك، ايجاد يك جشهمانداز واضح و

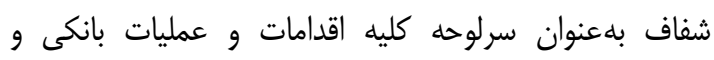

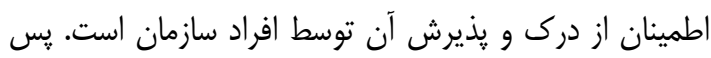
از تعيين دورنماى كلى بانك، مرحله بعد ايجاد حساسيت استراتزيك به معناى حس كردن استراتزيك محيط بيرونى و درونى بوده كه بر مبناى اين حساسيت ايجاد شده و اطلاعات

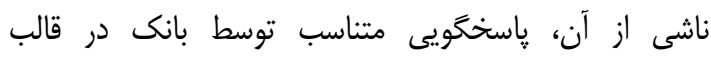
ياسخكويى درونى و بيرونى صورت مىيذيرد كه ايجاد

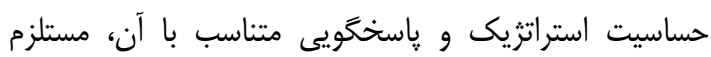
وجود يكسرى توانمندىهاى جمعى در قالب توانمندىهاى

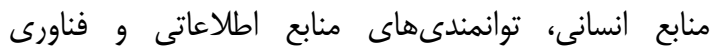
اطلاعات و توانمندىهاى زيرساختارى مىباشد. مىتوان كفت

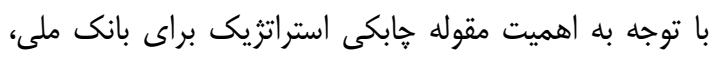
نياز به بسترسازى مناسب بلمنظور استقرار و بيادهسازى حابكى استراتزيك در بانك بهطور جدى احساس مى شود. شايان ذكر است اراده بر استقرار خابكى استراتزيك در بانكى

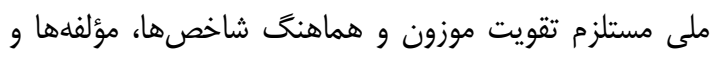

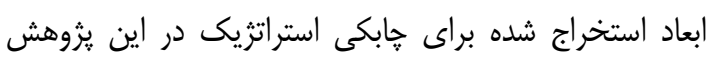

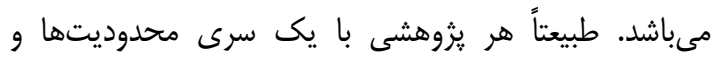
مشكلات همراه بوده و در واقع اين موارد جزء لاينفك آن بران مى باشند. اولين محدوديت، تعريف محدود جامعه آمارى و عدم

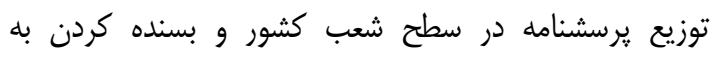
ادارات مركزى بانك ملى مستقر در سطح شهر تهران بود. ييخيرى از كاركنان براى مجاب كردن آنها براى صرف وقت در تكميل و ارسال جوابهاى دقيق و بلموقع، عدم نكرش مثبت برخى ياسخدهندكان و عدم رغبت و انكَيزه كافى آنان

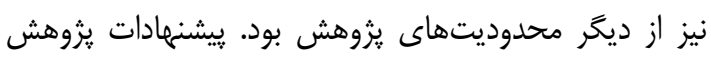
نيز بهشرح ذيل ارائه مى كردند:

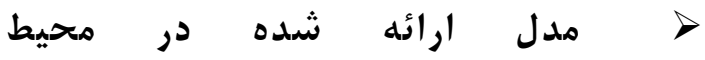

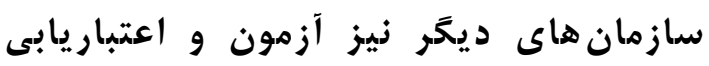 كَر مدل اعتباريابى شده در يزوهش حاضر، بهمنظور استقرار קابكى استراتزيك علاوه بر بانك ملى، در ساير}


Thesis for the Degree of master, Business Administration, pp1-136.

Ahammad Mohammad. Glaister and Gomes (2019) Strategic agility and human resource management, Human Resource Management Review, Online, <https://doi.org/10.1016/j.hrmr.2019.100700 $>$.

Cunha, Miguel Pina. Gomesa, Mellahib, Minerc and Regod (2019) Strategic agility through improvisational capabilities، Implications for a paradox-sensitive HRM, Human Resource Management Review, Article in press, Online, <https://doi.org/10.1016/j.hrmr.2019.100695 $>$, pp1-13.

Davenport, Thomas. Leibold \& Voelpel (2006) "Strategic Management in the Innovation Economy. Strategy Approaches and Tools for Dynamic Innovation Capabilities", Erlangen، Publics Publishing and Wiley-VCH.

Doz, Yves. \& Kosonen (2008) The dynamics of strategic agility، Nokia's rollercoaster experience, California Management Review, Vol. 50, Iss. 3, pp95-18.

Doz, Yves. \& Kosonen (2010) Embedding strategic agility، A leadership agenda for accelerating business model renewal, Long Range Planning, Vol.43, pp370-382.

Doz. Yves (2019) Fostering strategic agility، How individual executives and human resource practices contribute, Human Resource Management Review, Online, <https://doi.org/10.1016/j.hrmr.2019. 100693>.

Implement Consulting Group (2013) "Strategic agility; What does it take to build an agile organisation? ", Available at: www.implement.dk.

Kettunen, Petri (2009) Adopting key lessons from agile manufacturing to agile software product development, A comparative study", Tec novation, Vol. 29, Iss. (6-7), pp408-421.

Long, Carl (2000) Measuring your strategic agility, Consulting to Management, Vol. 11, Iss. 3, pp25-28.

$$
\begin{aligned}
& \text { داز، ايول و كاسانن (•وسו) "استراتزى سريع، نقش خابكى }
\end{aligned}
$$

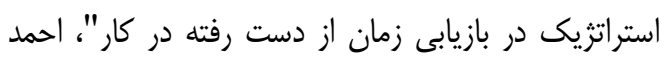

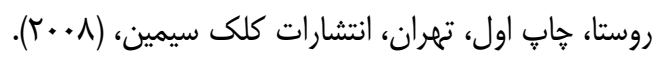

$$
\begin{aligned}
& \text { دهملايى، سيده ساناز (عوسا) "نقش خابكى استراتزيك در } \\
& \text { عملكرد رقابتى سازمان با تكيه بر نقش قابليت فناورانه }
\end{aligned}
$$

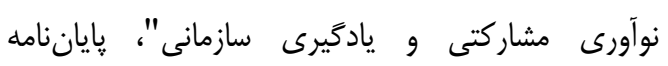

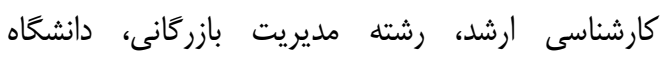

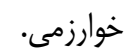

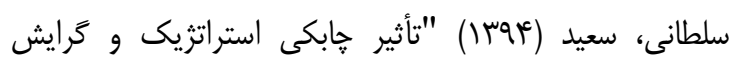

$$
\begin{aligned}
& \text { كارآفرينانه بر استراتزى سازمان (مورد مطالعه صنعت مواد } \\
& \text { غذايى)"، پايان نامه كارشناسى ارشد، رشته علوم انسانى، } \\
& \text { دانشخاه تربيت مدرس، دانشكده امور اقتصادى. }
\end{aligned}
$$

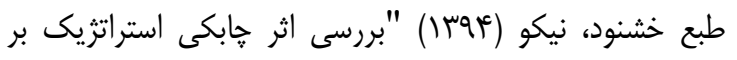

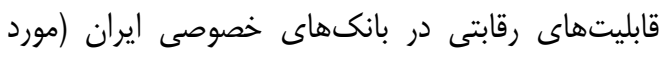

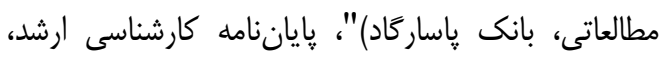

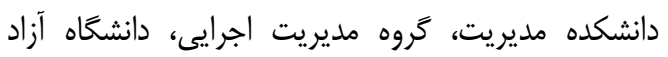

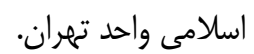

$$
\begin{aligned}
& \text { عباس يور، عباس. ميركمالى، حسام اميرى و مرادى (بوسا) }
\end{aligned}
$$

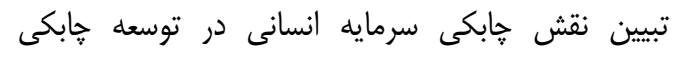

$$
\begin{aligned}
& \text { استراتزيك (مورد مطالعه، بانك انصار)، فصلنامه توسعه } \\
& \text { مديريت يولى و بانكى، شماره أ، بإييز، سال دوم. }
\end{aligned}
$$

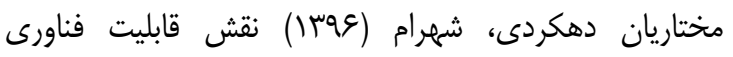

$$
\begin{aligned}
& \text { اطلاعات در توسعه جابكى استراتزيك و بهببود فعاليت }
\end{aligned}
$$

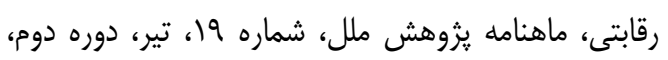

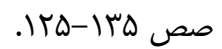

$$
\begin{aligned}
& \text { نعمتى، محمدعلى. همتى و خلقى (זوسו) طراحى مدل مزيت } \\
& \text { رقابتى شركتهاى توليدى بر مبناى تئورى قابليتهاى }
\end{aligned}
$$

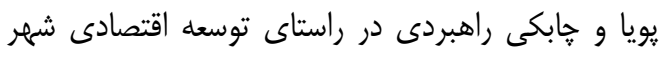

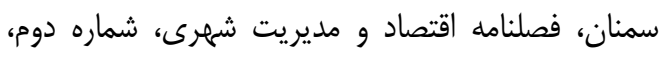

$$
\begin{aligned}
& \text { بهار. }
\end{aligned}
$$

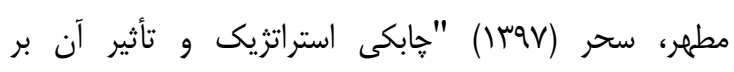

$$
\begin{aligned}
& \text { توانايىهاى رقابتى (شركت سبحان دارو)"، پايانانامه } \\
& \text { كارشناسى ارشد، رشته مديريت استراتزيك، موسسه } \\
& \text { آموزش عالى راهبرد شمال. }
\end{aligned}
$$

Abbu- Radi, Samer (2013) "Strategic Agility and Its Impact on the Operations Competitive Capabilities in Jordanian Private Hospitals", 


$$
\text { محمد كريمى،سيدنقوى،عادل صلواتى:اعتباريابى مدل مفهومى جابكى استراتزيكك در بانك ملى ايران }
$$

of Production Economics, Vol. 3, Iss. 2, Mavengere, Nicholas Blessing (2009) "Strategic pp181-196.

Weber, Yaakov \& Tarba (2014) "Strategic agility،

A state of the art introduction to the special section on strategic agility",California Management Review, Vol.56, Iss.3, pp5-12.

Xing, Yijun. Liu, Boojihawon \& Tarba (2019)

Entrepreneurial team and strategic agility، A conceptual framework and research agenda, Human Resource Management Review, Online,

<https//doi.org/10.1016/j.hrmr.2019.100696

\section{$\geq$.} agility of supply chains", Thesis for the Degree of master, Turku School of Economics.

Mavengere, Nicholas Blessing (2013) Information Technology Role in Supply Chain's Strategic Agility, International Journal of Agile Systems and Management,Vol. 6, No.1, pp. 7-24.

McCann, Joseph (2004) Organizational effectiveness، Changing concepts for changing environments, Human Resource Planning,Vol. 27, Iss. 1, pp42-50.

Ofoegbu, Onyema \& Akanbi (2012) The influence of strategic agility on the perceived performance of manufacturing firms in Nigeria, International Business \& Economics Research Journal, Vol. 11, No.2,Online:< http//dx.doi.org/10.19030/iber $. v 11 \mathrm{i} 2.6769>$

Ojha, Divesh (2008) "Impact of strategic agility on competitive capabilities and financial performance", Ph.D. thesis, Clesmon university.

Roth, Aleda (1996) Achieving strategic agility through Economies of Knowledge, Planning Review, Vol. 24, Iss. 2, pp30 - 36.

Sajdak, Maja (2015) Compilation of operational and strategic agility for ensuring the highest efficiency of company operations, Economics and Management, Vol. 7, Iss. 2, pp20-25.

Sambamurthy, Vallabh. Bharadwaj \& Grover (2003) Shaping agility through digital options، reconceptualizing the role of information technology in contemporary firms, MIS Quarterly, Vol. 27, Iss. 2, pp237263.

Setia, Pankaj. Sambamurthy \& Closs (2008) Realizing business value of agile IT applications, antecedents in the supply chain networks, Information Technology and Management, Vol. 9, Iss. 1, pp5-19.

Shin, Hojung, Lee, Kim \& Rhim (2015) Strategic agility of korean small and medium enterprises and its influence on operational and firm performance, International Journal 


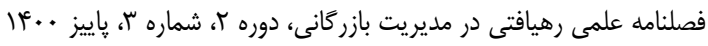

